\title{
Statistics and the Canada Millennium Scholarship Foundation
}

\section{DALE KIRBY}

Ontario Institute for Studies in Education of the University of Toronto (OISE/UT)

\section{ABSTRACT}

This article critiques the Canada Millennium Scholarship Foundation's claim that recent research indicates that "Canada must move beyond (its focus on) student financial assistance" as a means of ensuring access to postsecondary education since "three out of four Canadian youth cite non-financial reasons to explain why they chose not to pursue postsecondary studies." This article argues that the Scholarship Foundation's research claims are not entirely accurate and are presented in a manner that is misleading.

\section{RÉSUMÉ}

Cet article est une critique de l'affirmation de la Fondation des bourses du millenaire du Canada selon laquelle "le Canada doit faire plus que (de se concentrer sur) l'aide financière aux étudiants" pour assurer l'accès a l'éducation postsecondaire, puisque, dit-elle, "trois étudiants canadiens sur quatre invoquent des raisons autres que financières pour expliquer pourquoi ils ont choisi de ne pas poursuivre d'études au niveau postsecondaire." Selon le présent article, les allégations de la Fondation ne sont pas une juste appréciation des faits et sont presentées de façon à induire le public en erreur. 
The Canada Millennium Scholarship Foundation was established by an Act of Parliament in June of 1998 with a mandate to manage and allocate, through scholarships and bursaries, a $\$ 2.5$ billion endowment from the Government of Canada. A nonprofit organisation, the Scholarship Foundation is overseen by a government-appointed Board of Directors. In January of 2001, the Scholarship Foundation announced that it was establishing a program of research, intended in part to determine the role played by money, or lack thereof, in students' decisions to undertake studies at the postsecondary level. The Scholarship Foundation subsequently released a document outlining the directions and major themes for this research program (Canada Millennium Scholarship Foundation, 2001). The choice of title for the Scholarship Foundation's research profile, Does money matter?: The research program of the Canada Millennium Scholarship Foundation, is interesting in terms of the durability of the debate regarding access to postsecondary learning opportunities in Canada. More than twenty years prior to the aforementioned announcement from the national Scholarship Foundation, a similarly titled report, Does money matter?: Prospects for higher education in Ontario, was published by Porter, Porter, and Blishen (1979). Like the Scholarship Foundation, the authors of this study on postsecondary accessibility in Ontario noted that:

University education is expensive, both because of the earnings a student must forego in order to attend and because of the actual costs of tuition fees, books and living. Therefore, if students from lower income families are less likely to aspire to or expect to go to university than children from higher income families, it seems reasonable to conclude that cost must be a factor. (p. 31)

Indeed the cost impediment that exists for some Canadian youth, who would otherwise participate in postsecondary study, has long received the attention of public policy makers. Since the end of the 1930's there has continuously been some type of direct governmental involvement in funding postsecondary education. As might be anticipated, this assistance has taken many forms over time. There is a general agreement that the purpose of student financial aid is to provide support 
to those individuals who, as a direct result of the heavy financial commitment that is required, would not have been likely to have the opportunity to participate in postsecondary education. The existence of government-sponsored student financial assistance programs, at the federal and provincial levels, indicates there is a public interest in ensuring that all qualified Canadians are able to access postsecondary education, regardless of their socioeconomic background.

Generally, government-sponsored student aid has been directed towards enhancing college and university accessibility by providing grants, guaranteed loans, or both, and more recently, helping students manage increased student loan debt. Regrettably, as noted by the Millennium Scholarship Foundation, there have been relatively few empirical studies of postsecondary students' experiences with the needbased financial aid system in Canada (Looker \& Lowe, 2001). In one Canadian study, Gilbert and Auger (1988) found that government student loan programs enhance public participation in postsecondary education and that a lack of financial resources appeared related to students' premature departure from their studies. Likewise, a number of American studies have found that financial aid strategies have a substantial influence on enrollment decisions, that student financial aid is positively associated with student persistence, and that in some cases student loans promote persistence (St. John, Kirshstein, \& Noell, 1991; Somers \& St. John, 1993; Volkwein, Szelest, Cabrera, \& Napierski-Pranel, 1998). Some of the trends in Canadian student borrowing are a cause for public concern. The available data shows that there have been substantial increases in the amount borrowed by students, with the amount borrowed increasing each year. This has been accompanied by a rise in debt burdens over time as observed from debt-to-earnings ratios. There have been steady increases in the proportion of borrowers who experience repayment difficulties. In addition, there is increasing evidence that students from lower socioeconomic backgrounds are more likely to borrow and subsequently face high debt loads (Bourgoin, 1995; Clarke, 1998; Finnie \& Garneau, 1996; Plager \& Chen, 1999).

The decision to study at the postsecondary level results from a complex interplay of a number of variables. While no single combination of 
variables has been shown to account for all of the variance observed in research into student choice and participation, factors such as socioeconomic status and rural/urban background are very important in the decision-making process. These factors are also highly useful in the examination of various student behaviours at the college and university level (e.g., financial behaviour, attrition/persistence). Bourdieu (1986, 1977) accounts for the differences in postsecondary participation behaviours between youths of differing socioeconomic backgrounds using the theory of cultural capital. Cultural capital consists of the knowledge, preferences, and attitudes of the predominant cultural sensitivities possessed by individuals from middle and upper-level socioeconomic backgrounds. Generally, cultural capital is conveyed from parents to children, includes the preferences for achieving an education beyond the level of secondary school, and enables families from middle and upper-level socioeconomic backgrounds to maintain their status from one generation to the next (McDonough, 1997). In essence, one's financial prosperity is strongly connected to a positive predisposition toward postsecondary education. Those students possessing the greatest quantities of cultural capital come from the higher socioeconomic classes and are more likely to succeed educationally.

A recent report from Statistics Canada indicates that young people from higher-income families were 2.5 times as likely as those from lower-income families to have participated in university-level education (Statistics Canada, 2001). The study also found that young people between the ages of 18 and 21 who came from low-income backgrounds were less likely to have enrolled in any form of postsecondary study and that this participation gap was particularly pronounced for universitylevel studies. In light of the release of this report, it was with much surprise that, in a January 2002 press release, the Millennium Scholarship Foundation announced that "Canada must move beyond student financial assistance" because "new Canada Millennium Scholarship Foundation research" indicated that "three out of four Canadian youth cite non-financial reasons to explain why they chose not to pursue postsecondary studies" (Canada Millennium Scholarship Foundation, 2002). With closer investigation it is obvious that the Scholarship Foundation's 
"new" research is indeed not entirely new. In fact, the Scholarship Foundation's conclusion that over three-quarters of the Canadian youth who choose not to participate in postsecondary education choose not to do so for non-monetary reasons is based on an analysis of data collected in 1991 for Statistics Canada's School Leavers Survey (Foley, 2001). There are two significant problems with the Scholarship Foundation's analysis and representation of this data.

The first problem with the Scholarship Foundation's interpretation of the 1991 School Leavers Survey data relates to the purpose and methodology of the original study from which the data was extracted. The School Leavers Survey was designed and conducted in order to estimate the numbers of high school non-completions and to identify any circumstances associated with dropping out of high school. This survey was not designed or intended to be used to investigate reasons why students choose not to attend postsecondary level education. In keeping with this, the School Leavers Survey included just one questionnaire item, out of several hundred, related to the question of postsecondary choice. The question was, "We are interested in knowing why you did not continue to university, college, or CEGEP. What was the most important reason?" The possible responses were:

1. Did not have enough money to continue;

2. Wanted to raise a family;

3. Had no interest in pursuing further education;

4. Had a good job;

5. Marks too low;

6. Couldn't decide what to do;

7. No program of interest was offered close to home;

8. Wanted to take some time off from studying;

9. Other reason; and

10. Don't know.

As Foley (2001) indicated in a study commissioned by the Scholarship Foundation, $77 \%$ of those who participated in the School Leavers Survey chose an answer other than the first one, the only explicitly financial reason available from the list of responses. As indicated earlier 
in this article, postsecondary choice process is complex and involves multiple intervening variables (Hossler, Schmit, \& Vesper, 1999; McDonough, 1997). The School Leavers Survey was not intended to investigate postsecondary choice or any financial matters related to this decision-making process. It is therefore imprecise and misleading for the responses to this single questionnaire item to be touted as evidence that "Canada must move beyond student financial assistance" because "three out of four Canadian youth cite non-financial reasons to explain why they chose not to pursue postsecondary studies."

A second significant problem with the Scholarship Foundation's portrayal of School Leavers Survey data relates to the "age" of the data itself. The School Leavers Survey data was collected in 1991. In terms of its contribution to the current debate about postsecondary accessibility, Foley's (2001) analysis of this data hardly constitutes "new research" as was claimed by the Scholarship Foundation. Like the study by Porter, Porter and Blishen (1979), the data collected for the School Leavers Survey could provide some historical perspective, had it been intended for an examination of the process of postsecondary choice. However, the 11 year-old data from the School Leavers Survey provides little or no information about the challenges faced by today's postsecondary bound youth, particularly since both the cost and options for financing postsecondary education are much different today than in the early 1990s. For example, since the mid-1990s postsecondary tuition has increased significantly in most of the Canadian provinces, federal and provincial student loan programs have undergone substantial revisions, and postsecondary student debt is much higher. Continuing on to college or university today is much different, at least in financial terms, than it was in 1991.

Clearly, there are problems with the manner in which the Canada Millennium Scholarship Foundation has interpreted and reported on the results of Foley's (2001) re-examination of the 1991 School Leavers Survey. The declaration that "Canada must move beyond student financial assistance" is not justified by the claim that "three out of four Canadian youth cite non-financial reasons to explain why they chose not to pursue postsecondary studies." Even if the Scholarship Foundation had pronounced that "eleven years ago in 1991 three out of four 
Canadian youth cited non-financial reasons...," there would still be problems with the conclusions drawn from the data, given the original purpose and methodology of the School Leavers Survey. More concerning is that the intended audience of the press release issued by the Canada Millennium Scholarship Foundation would include the mainstream media rather than being limited to a more research savy academic community. While it is assumed that the audiences of academic publications are comprised of experienced consumers of research, the general public and the mainstream media are not, in many cases, adept critics of statistics and research methodologies. For this reason, standards in research, and survey research in particular, are tremendously important. Excellence and accuracy in survey research demands that data analysis and interpretation be competent and clear and that any findings are presented fully and fairly. The data collected must be critically examined in any search for their meaning. The findings and interpretations must be presented in the most objective manner. If the Canada Millennium Scholarship Foundation is truly interested in answering the question "Does Money Matter?" it would be better served by more accurate interpretation and presentation of the research it commissions.

\section{References}

Bourdieu, P. (1977). Cultural reproduction and social reproduction. In J. Karabel \& A.H. Hasley (Eds.), Power and ideology in education. New York, NY: Oxford University Press.

Bourdieu, P. (1986). The forms of capital. In J.C. Richardson (Ed.), Handbook of theory and research for the sociology of education. New York, NY: Greenwood Press.

Bourgoin, B. (1995). Financial aid to postsecondary students. Education Quarterly Review, 2(1), 10-19.

Canada Millennium Scholarship Foundation. (2001). Does money matter?: The research program of the Canada Millennium Scholarship Foundation. Ottawa, ON: Canada Millennium Scholarship Foundation. 
Canada Millennium Scholarship Foundation. (2002, January 22). Canada must move beyond student financial assistance: Non-financial barriers to postsecondary education must be attacked to address the problem, according to a summary of new Canada Millennium Scholarship Foundation research. Ottawa: Canada Millennium Scholarship Foundation.

Clarke, W. (1998). Paying off student loans. Canadian Social Trends, 51, 24-28.

Finnie, R., \& Garneau, G. (1996). Postsecondary student borrowing. Education Quarterly Review, 3(2), 10-34.

Foley, K. (2001). Why stop after high school? A descriptive analysis of the most important reasons that high school graduates do not continue to PSE. Ottawa: Canada Millennium Scholarship Foundation.

Gilbert, S.N., \& Auger, M. (1988). Student finances and university attrition. Ottawa, ON: Department of the Secretary of State of Canada.

Hossler, D., Schmit, J., \& Vesper, N. (1999). Going to college: How social, economic, and educational factors influence the decisions students make. Baltimore, MD: Johns Hopkins University Press.

Looker, E.D., \& Lowe, G.S. (2001). Postsecondary access and student financial aid in Canada: Current knowledge and research gaps. Ottawa, ON: Canadian Policy Research Networks.

McDonough, P.M. (1997). Choosing colleges: How social class and schools structure opportunity. Albany, NY: State University of New York Press.

Plager, L., \& Chen, E. (1999). Student debt from 1990-91 to 1995-96: An analysis of Canada Student Loans data. Education Quarterly Review, 5(4), 10-35.

Porter, M.R., Porter, J., \& Blishen, B.R. (1979). Does money matter? Prospects for higher education in Ontario. Toronto, ON: Macmillian of Canada.

St. John, E.P., Kirshstein, R.J., \& Noell, J. (1991). The effects of student financial aid on persistence: A sequential analysis. Review of Higher Education, I4(3), 383-406.

Somers, P.A., \& St. John, E.P. (1993). Assessing the impact of financial aid offers on enrollment decisions. Journal of Student Financial Aid, 23(3), 7-12.

Statistics Canada (2001, December 6). Participation in postsecondary education and family income. The Daily. Ottawa, ON: Ministry of Supply and Services.

Volkwein, J.F., Szelest, B.P., Cabrera, A.F., \& Napierski-Pranel, M.R. (1998). Factors associated with student loan default among different racial and ethnic groups. Journal of Higher Education, 69(2), 206-237. 